\title{
Evaluation of Successful Landing of Aerial Robot on a Charging Platform
}

\author{
DMITRY D. KUDASHOV, Ufa State Aviation Technical University (USATU), \\ Ufa, Russia \\ Professional paper \\ UDC: 007.52:519.711 \\ ROMAN V. SIZONENKO, Ufa State Aviation Technical \\ University (USATU),Ufa, Russia \\ DOI: 10.5937/tehnika1604585K
}

\begin{abstract}
Various methods for recharging of aerial robot onboard accumulator are known. The simplest method is periodical landing of aerial robot on a special platform and charging the robot from the terrestrial source. It is possible to connect onboard and terrestrial parts of the charging system by means of platforms with open contact pads. The advantage of such platforms compared to plug couplers is the lack of necessity for accurate landing of robots and availability to serve a group of robots simultaneously. Analysis of successful landing probability versus onboard landing electrodes configuration was carried out by means of the special simulation program. The influence of uncertainty of contact points coordinates on probability of successful landing was investigated. Four variants of contact points positioning were considered: 3-, 4-, 6- and 8-point schemes with points in regular polygon vertexes. The optimal ranges of polygons' circumradius providing $100 \%$ successful landing probability were found out for each scheme.
\end{abstract}

Key words: aerial robot, landing, modeling, landing platform, statistical test

\section{INTRODUCTION}

One of the problems for using aerial robots is relatively small duration of the flight because of limited specific energy intensity of power sources. This problem is actually for vehicles with vertical take-off (helicopters, multicopters and etc. [1]), which are more energy-intensive as compared with aircraft type vehicles.

In most cases on-board power sources are lithiumion battery cells or batteries. Therefore, the most natural solutions to increase the operating time of the aerial robot is landing on the special service platform, which involves the exchange of power sources or their charging.

Although there are other ways to extend the life of the aerial robot [2], such as charging in the air by terrestrial laser [3]; charging from power lines [4]; the aerial robots powered by the thin cable that connects the device to the land-based sources [5]. While these methods are quite exotic and are not considered here.

Optimal solution is the terrestrial charging platfo-

Author's address: Dmitry Kudashov, Ufa State Aviation Technical University (USATU), Ufa, Karla Marksa, 12, Republic of Bashkortostan, Russia

Paper received: 11.05.2016.

Paper accepted: 29.07.2016. rm with plane-parallel contacts. Half of terrestrial contacts is connected to "plus" of the terrestrial power source and the other half - to "minus", at that polarities are alternated (figure 1).

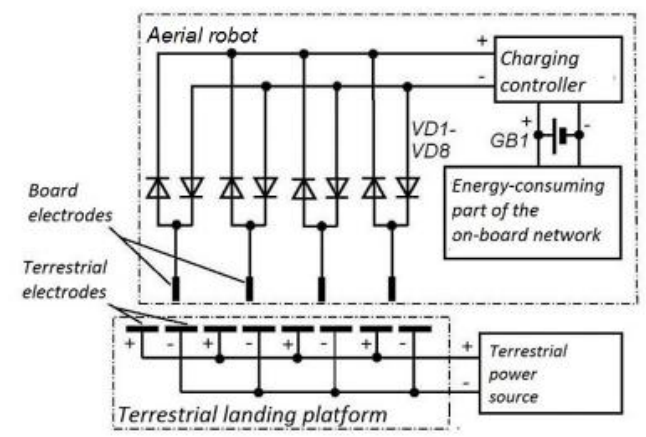

Figure 1 - Charging station structure

Due to the described geometric features, the short circuit by the board electrode of nearby plane-parallel landing electrodes is excluded. For any landing option, the situation when all four landing electrodes contact with only one plane terrestrial contact is excluded. But at the landing is provided the bipolar of the board electrodes (at least one of them will have a different polarity from the other).

The most popular touch point schemes of on-board electrodes are 3-, 4-, 6- and 8-point schemes with points in regular polygon vertexes. Touch point location of on-board landing electrodes should be subject 
to certain geometric relations (detailed in [6]). Figure 2 shows the maximum permitted variants of arranging for cases with the different regular polygons.

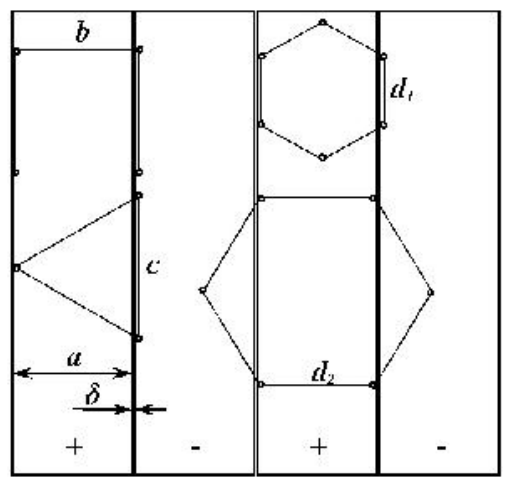

Figure 2 - Close to the maximum permissible options for on-board landing electrodes arranged at the vertices of equilateral triangles and hexagons

Observance of these ratios guarantee the excluding of situation when all on-board landing electrodes contact with only one plane terrestrial contact.
Also, we analyzed the way in which the successful landing probability depends on the quantity of touch points, the size of the respective regular polygon, as well as the contact points coordinates uncertainty. Consideration of this issue is devoted to this article.

\section{DESCRIPTION OF PROGRAM}

For evaluate probability of successful aerial robot landing was developed experimental aerial robot behavior model. In this model landing is successful if aerial robot touches charging platform with all contacts, and if two contact has different charges. Simulation landing was carried out using a program "CoptersLanding" written in the environment of Embarcadero RAD Studio XE in the language of Delphi. Program interface permits to change some simulation parameters, that is: the greatest distance between two charge contacts of aerial robot, size of contact strips, quantity of contact strips and touch point scheme. Charge contacts derivation was also used to refine model to actual conditions. Program maintain a computing of individual or multiple aerial robot launch (figures 3, 4).

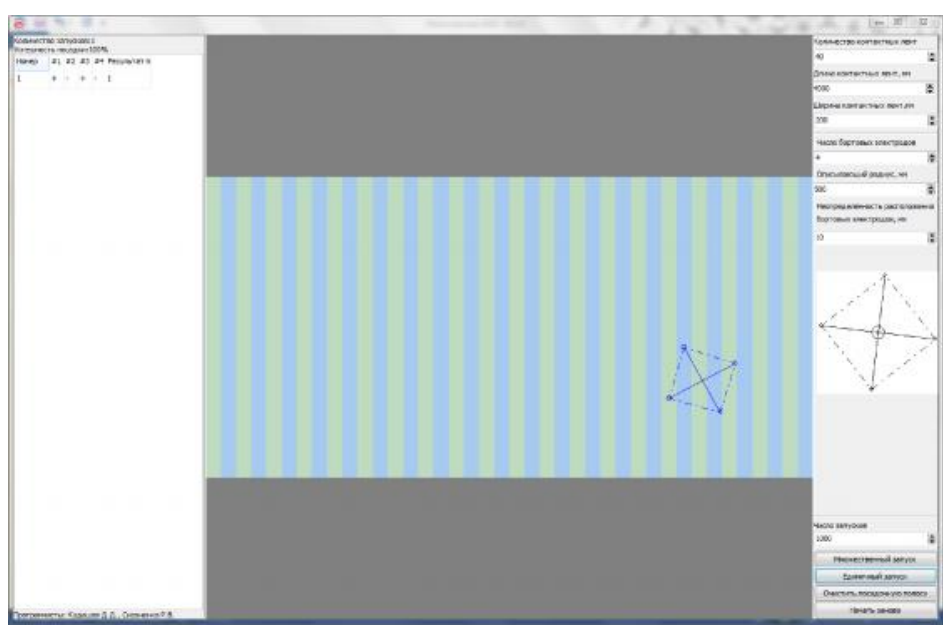

Figure 3 - Individual aerial robot launch

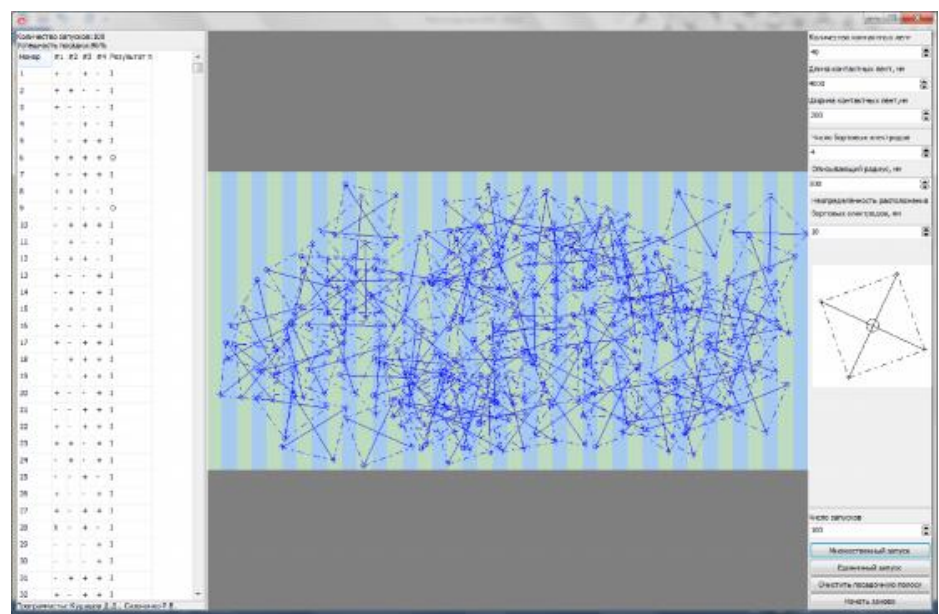

Figure 4-Multiple aerial robot launch 
Also, program works on the following algorithm:

- input the charging platform and aerial robot geometric parameters,

- $\quad$ set the launch mode

- getting the simulation results.

If on-board electrode touches the contact strip with negative charge, then in current launch this contact is recorded as ".". If on-board electrode touches the contact strip with positive charge, then in a current landing this contact is recorded as "+". A landing effectiveness is recorded as "I" (success) or " $\mathrm{O}$ " (fault), successful aerial robot landing must have minimum two contacts with different charges.

Aerial robot behavior model can evaluate successful landing probability aerial robot on the charging platform before real aerial robot launch. It can help to make a decision about optimal configuration of aerial robot and charging platform.

Next objective of this paper is a simulation of a few types aerial robot contact configuration: 3-, 4-, 6- and 8-points of aerial robot. Optimal distance between two aerial robot contacts associated with derivations are evaluated.

In all evaluable cases of landing we asked the next geometric parameters of platform:

- contact stripe count - 40,

- contact stripe size - 200x4000 mm,

The next parameters of aerial robot were varied:

- count of the touch points $(3,4,6,8)$,
- range of polygons' circumradius (50-400 mm),

- uncertainty of on-board electrode location (the limit values of the random deviations of coordinates $0,3,5,7,10 \mathrm{~mm}$ with a random distribution law).

\section{RESULTS OF AERIAL ROBOT LANDING SIMULATION}

During the simulation were correlations between geometric parameters of platform (the width of the contact stripes) and aerial robot (the side of the polygon with vertices at points of contacts on-board electrodes). These formulas were got on the basis of relationship between the radius of regular polygon incircle $r$ and the circumradius (the radius of circumscribed circle) $R$ - is the largest distance between two on-board electrodes [6]:

$$
r=R \cos \frac{\pi}{n},
$$

where $n$-count of the regular polygon sides.

Take into account also that the width of the platform contact stripe and the radius of incircle correspond as $a=2 r$.

Therefore,

$$
a=2 R \cos \frac{\pi}{n}
$$

Based on the getting formula were derived the result ratios (table 1) as well as the optimal values of the largest distance between two on-board electrodes at given initial data.

\begin{tabular}{|c|c|c|}
\hline Count of the touch points & $\begin{array}{l}\text { Optimal length of polygon side } c \text { and circumradius } R \\
\text { expressed in terms of contact stripe width } a\end{array}$ & $\begin{array}{l}\text { Expected optimal values } R, \mathrm{~mm} \text { at } a=200 \\
\mathrm{~mm}\end{array}$ \\
\hline 3 & $\begin{array}{l}c=1,155 a \\
R=0,667 a\end{array}$ & $R=133,4$ \\
\hline 4 & $\begin{array}{c}c=a \\
R=0,707 a\end{array}$ & $R=141,4$ \\
\hline 6 & $\begin{array}{l}0,577 a<c<a \\
0,577 a<R<a\end{array}$ & $115,4<R<200$ \\
\hline 8 & $\begin{array}{c}0,414 a<c<a \\
0,541 a<R<1,307 a\end{array}$ & $108,2<R<261,4$ \\
\hline
\end{tabular}

Table 1. «Theoretical estimated optimal ratios for geometric parameters of aerial robot and contact stripe width»

The obtained ratios were tested by program «CoptersLanding». Results for zero value of the uncertainty

of on-board electrode location are represented on the graphs (figures $5-8$ ).

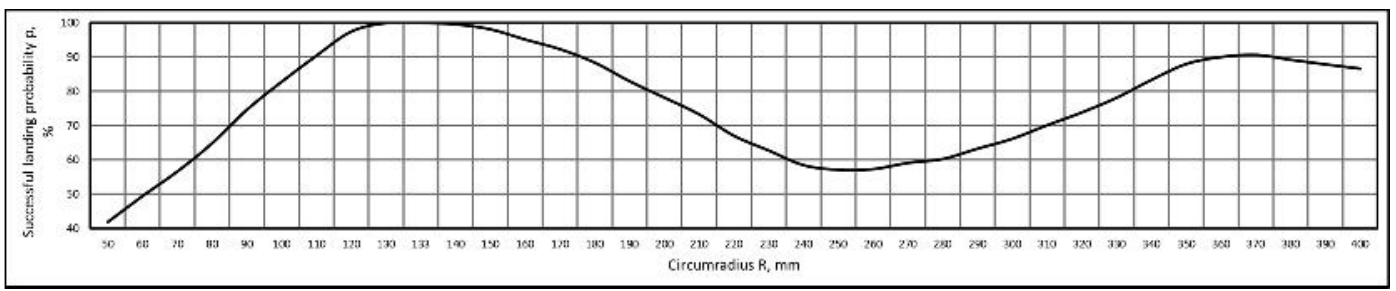

Figure 5-Successful landing probability for 3-point scheme of on-board landing electrodes 


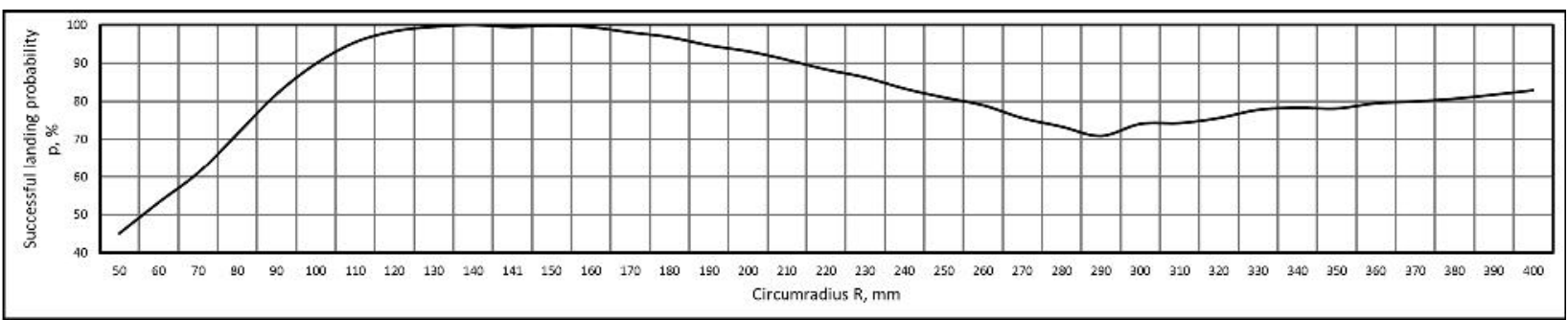

Figure 6-Successful landing probability for 4-point scheme of on-board landing electrodes

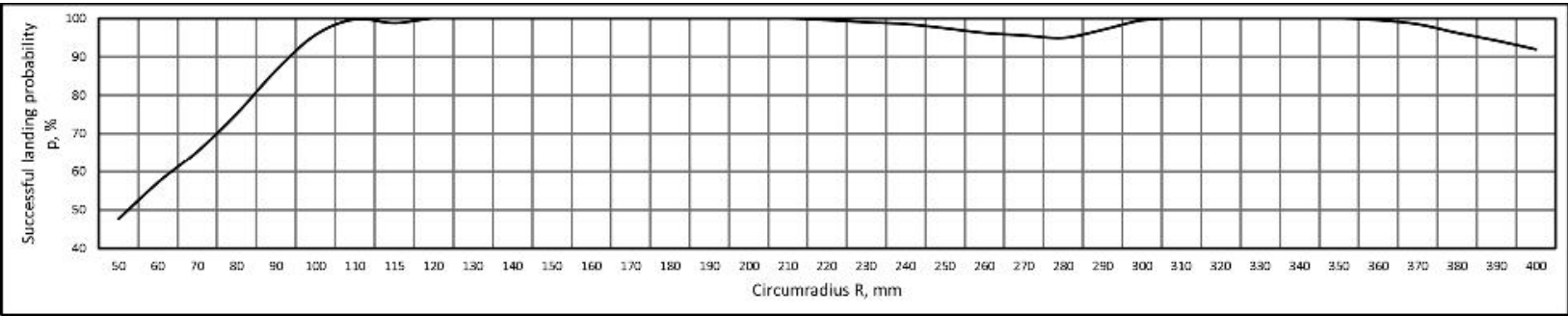

Figure 7 - Successful landing probability for 6-point scheme of on-board landing electrodes

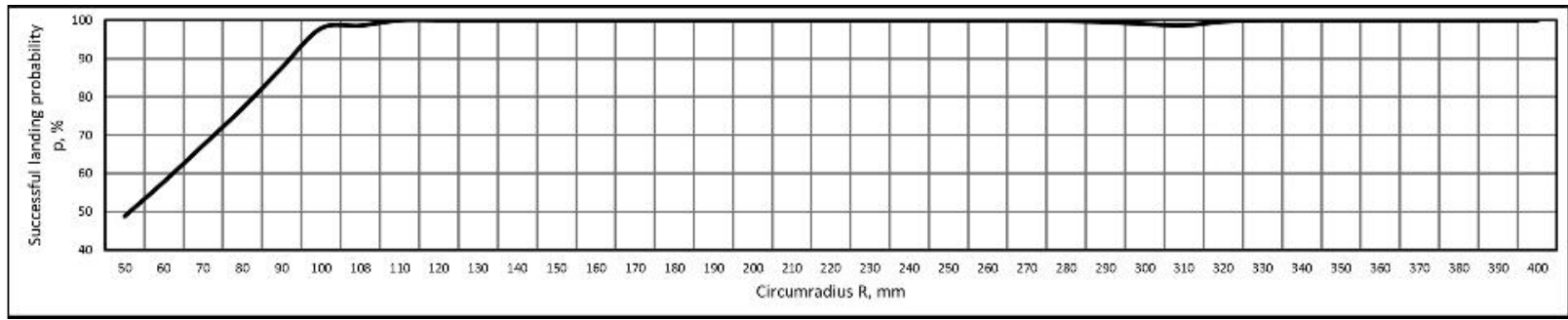

Figure 8-Successful landing probability for 8-point scheme of on-board landing electrodes

From the graphs it follows that for all researched configurations of on-board electrodes there are the optimal ranges of aerial robot sizes (the largest distance between two on-board electrodes $R$ ) in which the landing is successful always. At the increase of touch point count this range is growing.

Due to the developed program has the possibility to analyze the results of aerial robot landing to the charging platform before its design. This simulation is the only way to evaluate the dependence between the sizes of aerial robot, charging platform and the successful landing probability. The values of optimal ranges of aerial robot sizes are listed in table 2.

Also, the separate series of simulation was held for evaluation the impact of uncertainty of on-board electrodes loaction to the successful aerial robot landing probability. The uncertainty of on-board electrodes location was given by its limit values in absolute units (millimeters).

Table 2. "The optimal zones of researched configurations"

\begin{tabular}{|c|c|}
\hline Count of the touch points & Range of values $R, \mathrm{~mm}$ \\
\hline 3 & $120-150$ \\
\hline 4 & $130-150$ \\
\hline 6 & $110-120,190-205$ \\
\hline 8 & $105-110,190-205$ \\
\hline
\end{tabular}

Behavior of dependences $p=f(R)$ is researched in the optimal ranges obtained earlier for the values $\mathbf{Y}=0$, $3,5,7,10 \mathrm{~mm}$.

These are the typical values for real conditions when the uncertainty of on-board electrodes location may be due to the factors such as technological errors of on-board electrodes mounting or non-rigidity of the support legs.

Results for 3-, 4-, 6- и 8-point on-board electrodes configurations of the aerial robots are represented in figures $9-12$.

From the graphs can be seen that for 3- and 4-point schemes which has zone of optimal values $R$ is relatively narrow, already at $\gamma=5 \mathrm{~mm}$ or more is practically impossible to achieve a completely successful landing.

For 6- and 8-point configurations, started from certain values $R$, the uncertainty of on-board electrodes location $\gamma$ ceases to have any effect to the successful aerial robot landing probability.

Range of values $R$, where $p=100 \%$ at any values $\gamma<10 \mathrm{~mm}$, for 6-point to the values for order of 260 $\mathrm{mm}$, i.e. to the end of the optimal range, and for 8-point it almost never ends. Therefore, the increase of onboard electrode touch points ensures a $100 \%$ probability of successful landing at any value of the original data. 


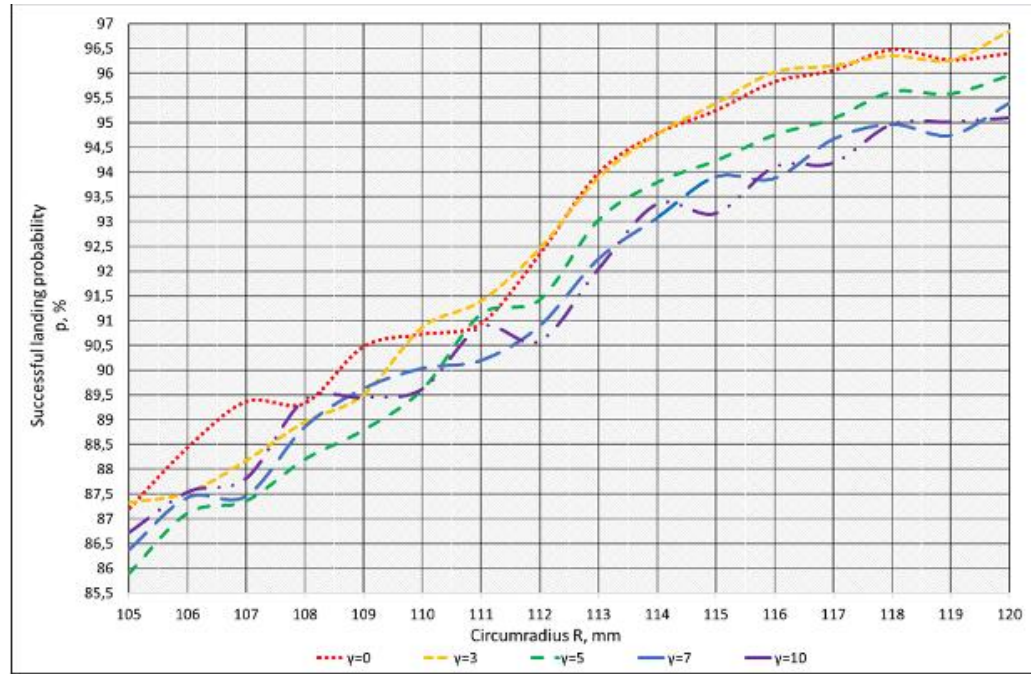

Figure 9 - Dependences of successful landing probability from circumradius $R$ at varying uncertainty of onboard electrodes location $\gamma$ for 3-point scheme

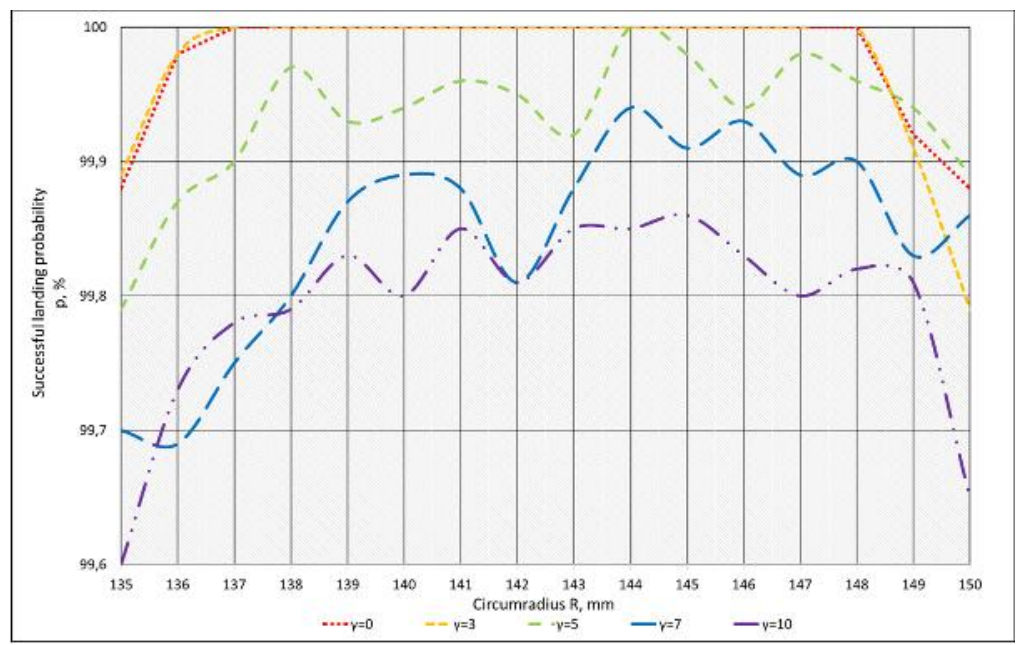

Figure 10 - Dependences of successful landing probability from circumradius $R$ at varying uncertainty of onboard electrodes location $\gamma$ for 4-point scheme

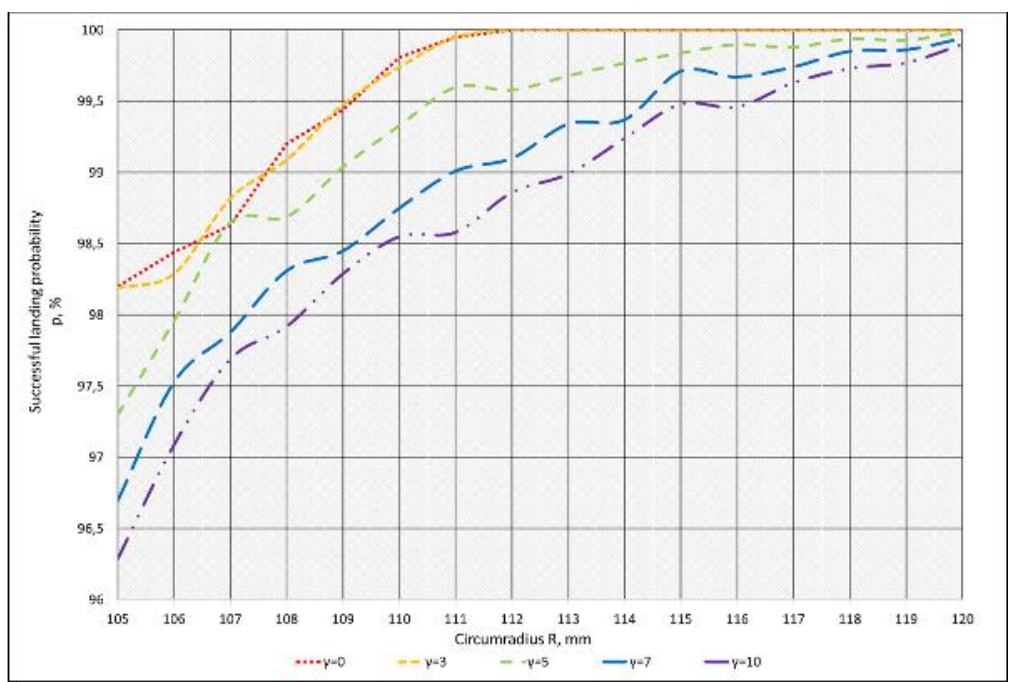

Figure 11 - Dependences of successful landing probability from circumradius $R$ at varying uncertainty of onboard electrodes location $\gamma$ for 6-point scheme 


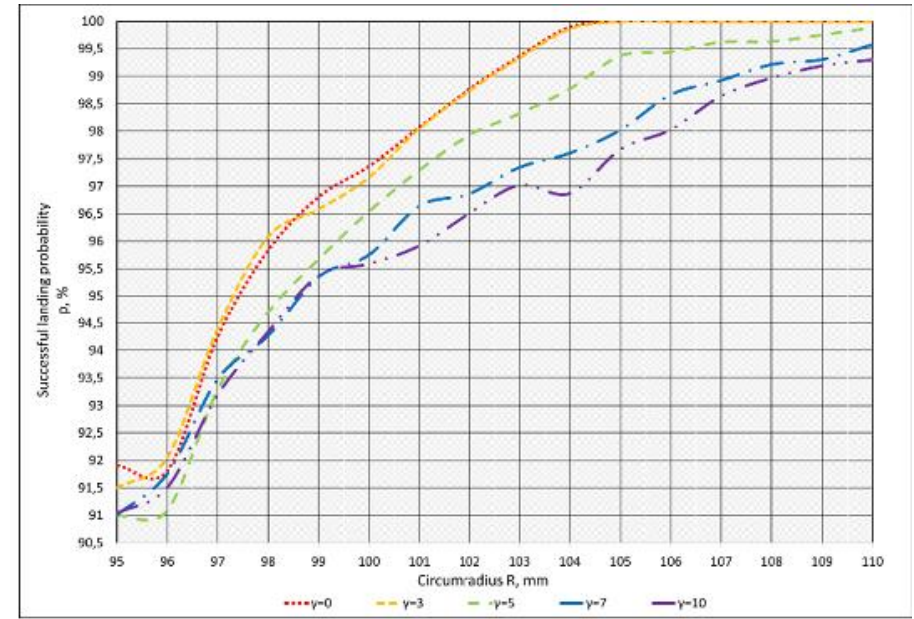

Figure 12 - Dependences of successful landing probability from circumradius $R$ at varying uncertainty of onboard electrodes location $\gamma$ for 8-point scheme

\section{CONCLUSION}

Developed simulation program allows to estimate the successful landing probability of aerial robot having a regular arrangement of on-board electrodes on the charging platform having a plane-parallel contacts. Touch points of on-board electrodes located at the vertices of a regular polygon. Designed tool helps select the right ratio between the geometric parameters of the charging platform and aerial robot.

\section{REFERENCES}

[1] Fetisov V. S. (ed.), et al, Unmanned aviation: terminology, classification, state of the art, (in Russian). Ufa: FOTON, 2013. Available: http://vositef.url.ph/index.files/ PUBL/UAV2014.pdf

[2] Fetisov V.S., Tagirov M.I., Mukhametzyanova A.I., "Charging for electric UAVs: review of existing developments and perspective solutions," (in Russian), in Aviakosmicheskoye priborostroyeniye, vol. 11, pp. 7-26, 2013. Available: http://vositef.url.ph/index.files/PUBL/Fetisov_et_al_ASI-2013-11.pdf

[3] Nugent T. J, Kare J. T, Power for UAVs. White Paper of Laser Motive, 2010 [Online]. Available: http://lasermotive. com/wp-content/uploads/2010/04/Wire-less-Power-for-UAVs-March2010.pdf

[4] Marshall P. T, Power line sentry charging. US Patent 7318564. Publ. 15.01. 2008.

[5] TheHoverMast from Sky Sapience [Online]. Available: http://skysapience.com, Dec. 12, 2014

[6] Fetisov V.S, Akhmerov Sh.R. Sistemy podzaryadki elektricheskikh bespilotnykh letatelnykh apparatov s vertikalnym vzlyotom-posadkoi na osnove posadochnykh platform s ploskoparallelnymi otkrytymi kontaktnymi ploschadkami [ harging stations for electrical unmanned aerial vehicles with vertical takeoff-and-landing based on landing platforms with plane-parallel open contact pads] // Pribory i sistemy. Upravlenie, control, diagnostika [Instruments and Systems: Monitoring, Control, and Diagnostics]. 2015. № 7. P. 41-49.

\section{REZIME}

\section{ODREĐIVANJE VEROVATNOĆE USPEŠNOG SLETANJA VAZDUŠNOG ROBOTA NA PLATFORMU ZA PUNJENJE}

Poznati su različiti načini periodičnog punjenja baterija za vazdušne robote. Najprostiji je periodično sletanje vazdušnog robota na posebnu stanicu za punjenje i punjenje koje obezbeđuje izvor napajanja koji predstavlja nadzemnu konstrukciju. Moguće je spajanje nadzemnog i osnovnog dela sistema za punjenje pomoću platforme sa otvorenim kontakatima. Prednost ovakve platforme u poređenju sa utikačima za spajanje ogleda se u tome što se ne zahteva precizno sletanje vazdušnog robota; takođe, moguće je da se obavlja upravljanje sa nekoliko robota u isto vreme. Pomoću specijalnog programa za modeliranje, određena je verovatnoća uspešnog sletanja u vezi sa konfiguracijom tangentnih tačaka između osnovnih elektroda i traka platforme. Takođe je ispitivan uticaj neodređenosti koordinata kontaktnih tačaka na verovatnoću uspešnog sletanja. Razmatrane su 4 varijante položaja kontaktnih tačaka: šeme sa 3, 4, 6, 8 tačaka raspoređenih u temenima pravilnog mnogougla. Za svaku šemu je određen optimalni poluprečnik kružnice opisane oko mnogougla tako da verovatnoća uspešnog sletanja bude $100 \%$.

Ključne reči: vazdušni robot, sletanje, modeliranje, platforma za sletanje, statistički test 